\title{
Culto ao corpo e estilo de vida entre as mulheres
}

\author{
Marcela Carvalho Martins Amaral \\ Orientador: Lourdes Bandeira \\ Tese de Doutorado \\ Data da defesa: 22.09.2011
}

\begin{abstract}
A presente pesquisa tem por objetivo analisar o fenômeno do culto ao corpo, especialmente as práticas de culto à magreza entre mulheres. Com a pretensão de delimitar o fenômeno em questão, foram demarcadas três dimensões para a análise do culto ao corpo e à magreza: práticas estéticas, definidas como a frequência contínua em academias de ginástica; práticas alimentares, caracterizadas como a submissão a dietas e restrições alimentares; e, por fim, práticas interventivas, em que as mulheres se submetem a intervenções médico-cirúrgicas. Para desenvolver tal investigação, privilegiei os discursos de mulheres que frequentam uma academia de ginástica exclusivamente feminina no Distrito Federal, escolhida por ser a primeira franquia internacional voltada para o público feminino a atuar no Brasil. Dessa maneira, buscou-se investigar como as mulheres percorrem as dimensões do culto ao corpo, suas motivações e o sentido dado à magreza. Considerando o importante lugar do corpo no que concerne à construção das identidades de gênero, para pensar as práticas de culto ao corpo entre as mulheres, optou-se pela perspectiva de gênero, articulando um diálogo entre as teorias feministas e os referenciais da teoria social. Os discursos médico e midiático foram apontados como as principais fontes de "saberes" sobre o corpo e divulgadores de "certezas" sobre como gerir as corporeidades com vistas à saúde, à beleza, ao bem-estar e à felicidade, preservando, como ponto comum, a magreza. Através de imagens e discursos verbais e não verbais, a exaltada preocupação com o corpo, como uma obrigação para as muIheres, se tornou também um estilo de vida contemporâneo
\end{abstract}

Palavras-chave: Corpo, Mulher, Estilo de Vida, Saúde. 